\title{
Morphobiological, morphometric and ultrastructural characterization of sylvatic Trypanosoma cruzi isolates from Rio de Janeiro state, Brazil
}

\author{
C. Santos da Silva ${ }^{a, b}$, A. L. Carbajal-de-la-Fuente ${ }^{c}$, C. E. Almeida ${ }^{\text {, T. C. M. Gonçalves }}{ }^{a}$ \\ and J. Reis dos Santos-Mallet ${ }^{*}$
}

áLaboratório Interdisciplinar em Vigilância Entomológica de Diptera e Hemiptera - LIVEDIH, Instituto Oswaldo Cruz IOC, Fundação Oswaldo Cruz - FIOCRUZ, Av. Brasil, 4365, CEP 21040-900, Rio de Janeiro, RJ, Brasil

bPrograma de Pós-graduação em Biologia Animal - PPBA, Universidade Federal Rural do Rio de Janeiro -UFRRJ, Rodovia BR 465, Km 07, s/n, Zona Rural, CEP 23890-000, Seropédica, RJ, Brasil

'Laboratorio de Eco-Epidemiología, Instituto de Ecología, Genética y Evolución de Buenos Aires - IEGEBA, Consejo Nacional de Investigaciones Científicas y Técnicas de la República Argentina - CONICET, Facultad de Ciencias Exactas y Naturales, Universidad de Buenos Aires, Intendente Güiraldes, 2160,

Ciudad Universitaria, C1428EGA, Ciudad Autónoma de Buenos Aires, CABA, Argentina

dDepartamento de Biologia Animal, Instituto de Biologia, Universidade Estadual de Campinas - UNICAMP, Campus Universitário Zeferino Vaz, Rua Monteiro Lobato, 255, Barão Geraldo, CEP 13083-862, Campinas, SP, Brasil

*e-mail: jacenir@ioc.fiocruz.br

Received: June 22, 2017 - Accepted: November 17, 2017 - Distributed: May 31, 2019

(With 4 figures)

\begin{abstract}
Triatoma vitticeps is a triatomine with geographic distribution restrict to Brazil, which exhibits high prevalence of Trypanosoma cruzi natural infection. Of special epidemiologic concern, this species often invades households in the states of Rio de Janeiro, Minas Gerais and Espírito Santo. The objective of this study was to evaluate morphological and ultrastructural parameters on three T. cruzi isolates obtained from wild T. vitticeps specimens. The growth and cell differentiation of the parasite was evaluated through epimastigote and trypomastigote forms obtained in the growth curves for three distinct isolates. The maximum growth showed differences at the 20th day of the curve. Our in vitro results show a heterogeneity, regarding these features for samples cultivated under the same conditions. Morphometric analyzes based on the shape of epimastigotes and trypomastigotes corroborated such differentiation. These results highlight the need of better understanding the meaning of this diversity under an eco-epidemiological perspective.
\end{abstract}

Keywords: Trypanosoma cruzi, sylvatic isolates, morphobiology, ultrastructure, Rio de Janeiro state.

\section{Caracterização morfobiológica, morfométrica e ultraestrutural de isolados silvestres de Trypanosoma cruzi do estado do Rio de Janeiro, Brasil}

\begin{abstract}
Resumo
Triatoma vitticeps é um triatomíneo com distribuição geográfica restrita ao território brasileiro, apresentando alta prevalência de infecção natural pelo Trypanosoma cruzi. Esta espécie é relevante sob o ponto de vista epidemiológico por invadir domicílios com frequência nos estados do Rio de Janeiro, Minas Gerais e Espírito Santo. O objetivo deste estudo foi avaliar parâmetros morfológicos e ultraestruturais, em três isolados de T. cruzi obtidos a partir de triatomíneos silvestres. O crescimento e a diferenciação celular do parasita foi avaliado através das formas epimastigotas e tripomastigotas obtidas nas curvas de crescimento para os três isolados. O crescimento máximo mostrou diferenças no $20^{\circ}$ dia da curva. Nossos resultados in vitro mostram uma heterogeneidade, em relação a essas características para amostras cultivadas nas mesmas condições. As análises morfométricas baseadas na conformação de epimastigotas e trypomastigotes corroboraram essa diferenciação. Estes resultados ressaltam a necessidade de uma melhor compreensão do significado desta diversidade sob uma perspectiva eco-epidemiológica.
\end{abstract}

Palavras-chave: Trypanosoma cruzi, isolados silvestres, morfobiologia, ultraestrutura, estado do Rio de Janeiro. 


\section{Introduction}

Trypanosoma cruzi (Chagas, 1909) is the etiological agent of Chagas disease. This infection is responsible for high rates of morbidity, affecting around six to eight million people in Latin America and with 90-120 million people at risk (WHO, 2015). Chagas disease was originally considered enzootic; however, anthropogenic environmental modification has caused introduction of sylvatic triatomines to domestic environments, thereby increasing the probability of human infection (Forattini, 1980; Moser et al., 1989; Coura, 2013). Several studies have reported the role of sylvatic triatomines in Chagas transmission, as recently highlighted by Sangenis et al. (2015). These authors described an autochthonous case of Chagas in Rio de Janeiro attributed to Triatoma vitticeps (Stål, 1859), a sylvatic species found sporadically in domicile areas. This species has a known geographic distribution across Rio de Janeiro, Espírito Santo and Minas Gerais states where it is commonly found invading and colonizing domiciliary environments; harboring high prevalence of T. cruzi natural infection (Lent, 1942; Gonçalves et al., 1998; Santos et al., 2006; Silva, 2006; Souza et al., 2011).

Trypanosoma cruzi morphology, behavior, and biology, as well as clinical aspects of the disease have been the focus of several studies, as variations in the structures involved on the parasitism of the vertebrate host has been recorded (Vallejo et al., 1988; Hernández-Osorio et al., 2010; Garcia et al., 2011). T. cruzi polymorphism has been well studied since its discovery, when the distinct forms found in a myriad of vertebrates, invertebrates, and culture media were attributed to sexual dimorphism, and were referred to as a "morphological complex" (Devera et al., 2003). Dias (1940) discovered similarity among some trypanosomatid and T. cruzi in biometric studies of bats, and these organisms were there after referred to as the "Cruzi group", after which "Trypanosoma cruzi-like" became the preferred terminology to describe parasites that were morphologically indistinguishable from T. cruzi. However, Barreto (1965) proposed that some characters were important for parasite classification, including the following parameters for $T$. cruzi characterization: i) morphology; ii) biometric data, especially concerning the total body length and nuclear index; iii) viability in growth media; iv) evolution in the triatomine gut and development of metacyclic trypomastigotes in the insect posterior digestive tract; v) infectivity of animals raised in laboratory; vi) natural or experimental development in tissues of vertebrates hosts; and vii) development of immunity against virulent samples of human origin. According to Devera et al. (2003), after the detailed morphological descriptions of $T$. cruzi presented by Hoare (1972), there have been few studies addressing these issues. Recently, Silva-Júnior and Paiva (2017) evaluated the role of morphological characters in the phylogeny of some trypanosomatids, among them $T$. cruzi.

The use of techniques, such as scanning electron microscopy (SEM), cryo fracture, cytochemistry, immunocytochemistry, tridimensional reconstruction, and X-ray microanalysis, among others, has strongly contributed to our knowledge of pathogenic protozoa. Studies in the last 25 years have been focused on characterization of the cellular surface, including analysis of the glycocalyx, lipid bilayer, and subpellicular microtubules (Ribeiro et al., 2012). Although this approach has been widely used for identification of strains raised in various culture media, few studies are focused on parasite strains isolated from sylvatic triatomines. Trypanosoma cruzi populations exhibit strong intraspecific variability with respect to morphology, virulence, pathogenicity, host immune responses, and antigenic constitution; and this diversity may be associated with adaptation and survival in various distinct hosts (Villa et al., 2013). The characterization of parasites from distinct hosts via morphological, biological, biochemical, and molecular techniques have contributed to the development of immunoprophylactic and therapeutic methods.

This study explored the diversity in T. cruzi isolates from sylvatic triatomines from Rio de Janeiro state, through a morphobiological, biometric and ultrastructural characterization. The results will better describe trypanosomatid variation, yielding information that is useful for epidemiological purposes.

\section{Material and Methods}

\subsection{Insects}

Samples were isolated from Triatoma vitticeps specimens collected in Triunfo (22 02 ' $52^{\prime \prime}$ S; $\left.41^{\circ} 56^{\prime} 32^{\prime \prime} \mathrm{W}\right)$ in Santa Maria Madalena municipality (22॰5'4” S; 41 52 '7' W), Rio de Janeiro State, Brazil as show by Gonçalves et al. (1998). A total of three samples were used in this study: i) Sample SMM98 (initial letters indicate Santa Maria Madalena), obtained from $T$. vitticeps found in a deforested site, now serving as a banana plantation, this site is $250 \mathrm{~m}$ above mean sea level (amsl) and $3.5 \mathrm{~km}$ away from the village; ii) sample SMM36, isolated from $T$. vitticeps collected in an area located in a valley with conserved vegetation at $130 \mathrm{~m}$ amsl and $4 \mathrm{~km}$ away from the village and with a linear distance or $2 \mathrm{~km}$ from the first location and with mountains between the two sites at 400-900 m amsl; iii) sample SMM1, from $T$. vitticeps captured in the town of Vista Alegre in the neighboring Conceição de Macabu municipality.

\subsection{Biology of sylvatic isolates}

\subsubsection{Growth curves}

Growth curves were generating by rearing $T$. vitticeps sample isolates. We reared four subcultures, two in $\mathrm{NNN}+$ LIT medium and two in LIT medium according to Novy and McNeal (1904), Nicolle (1908) and Camargo (1964). Briefly, $2 \times 10^{6}$ organisms were plated on the media, and the day of this procedure was considered as day zero. The methodology was used according Sousa et al. (1994).

\subsubsection{Metacyclogenesis}

Metacyclogenesis was evaluated on the same days as the growth curves. Smears were made on the same day of counting to evaluate and quantify parasite forms (counting was stopped after reaching 200 of each parasite form). 


\subsection{Classic morphometry}

Morphometric analysis was based on parasite forms from axenic cultures on the $10^{\text {th }}, 17^{\text {th }}$ and $20^{\text {th }}$ days post-plating, and those found on smears prepared on the same day of growth curve cell counts (Silva, 2006; Sousa et al., 1994). Thirty epimastigotes and 30 trypomastigotes from each slide were measured (Hoare, 1972). Individual traits measured were as show the Figure 1A. Nuclear index
(NI) was calculated as the distance from the rear end of the body to the center of the nucleus $(\mathrm{PN}) /$ the distance from the anterior extremity of the body to the center of nucleus (NA) $[\mathrm{NI}=\mathrm{PN} / \mathrm{NA}]$. Kinetoplast index (KI) was calculated as the distance from the posterior extremity of the body to the center of the kinetoplast (PK)/ the distance from the center of the kinetoplast to the outside of the nucleus $(\mathrm{KN})[\mathrm{KI}=\mathrm{PK} / \mathrm{KN}]$ following (Schaub, 1989).

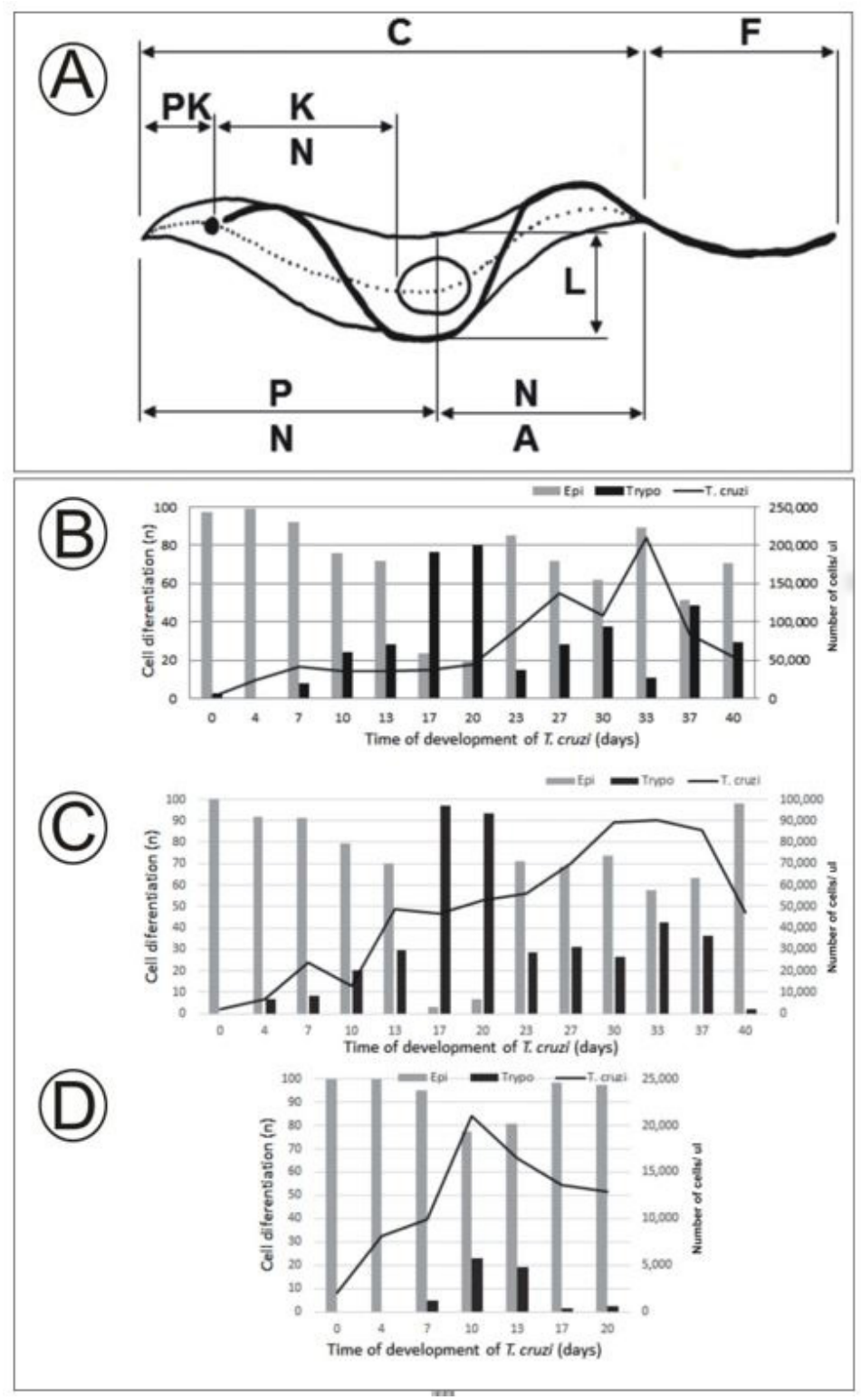

Figure 1. (A) Diagram of Trypanosoma cruzi with the measurements used for classic morphometry. The measurements were taken for the distance between the following points: $\mathrm{C}=$ body length (without a flagellum); $\mathrm{F}=$ free length of the flagellum; $\mathrm{L}=$ body width (at the middle of the nucleus); PK = distance from the posterior extremity of the body to the center of the kinetoplast, $\mathrm{KN}=$ away from the center of the kinetoplast outside the core; $\mathrm{PN}=$ away from the rear end of the body center of the core; NA = distance from the anterior extremity of the body to the center of nucleus (Modified from Hoare, 1972); (B-D) Growth curve and cell differentiation analysis for sample of T. cruzi isolated from Triatoma vitticeps. Samples SMM98 (B), SMM36 (C) and SMM1(D). Gray bars indicate the number of epimastigote (Epi); Black bars indicate the number of trypomastigotes (Trypo) and line indicates the growth of T. cruzi. 


\subsection{Ultrastructural analysis}

Samples were processed for transmission electron microscopy on the same day of the growth curve counts. The samples were fixed in $2.5 \%$ glutaraldehyde in $0.1 \mathrm{M}$ cacodylate buffer $(\mathrm{pH}$ 7.2) for one hour at room temperature, and post-fixed in $1 \%$ osmium tetroxide in the same buffer. After fixation, the material was washed in the buffer, dehydrated in graded acetone, and embedded in EPON resin (Ribeiro et al., 2012). Ultrathin sections were obtained using a Leica microtome and stained with uranyl acetate and lead citrate for microscopy using a Jeol JEM 1011 operated at $80 \mathrm{KV}$.

\subsection{Statistical analysis}

Means and standard deviations were obtained for all measurements. A Levene test was used to verify homogeneity of variance. An ANOVA was carried out to test differences between variables, and mean values for each group were contrasted using Tukey's test. The exactness and precision of measurements for each character were also calculated. All analyses were done in SPSS version 8.0 (SPSS Inc., Chicago, IL, USA). To test significant differences among samples SMM98, SMM36 and SMM1 (from different areas), the mean and standard deviation of each sample were calculated. After this, samples were separated according to the two parasite forms analyzed, controlling for forms obtained on different days. The cluster analysis that generated the dendogram was based on normalized mean values obtained by Principal Components Analysis (PCA) of each sample, done in JMP version 6.0 (SAS Institute, Inc., Cary, NC, USA).

\section{Results}

\subsection{Biology of sylvatic isolates}

\subsubsection{Growth curves}

The maximum growth in LIT medium on the $20^{\text {th }}$ day was 53,000 cells/ $\mu 1$ for SMM36; 44,000 cells/ $\mu 1$ for SMM98 and 12,875 cells/ $\mu 1$ for SMM1. SMM98 and SMM36 showed growth after day 20, therefore we continued until day 40 for these two samples. SMM98 showed the greatest growth on the $33^{\text {rd }}$ day, at which time we counted 210,000 cells/ $\mu 1$. Growth curve peaks for SMM36 occurred on the $33^{\text {rd }}$ day $(90,125$ cells $/ \mu 1)$, followed by a decline at day 40 (Figure 1B, C).

\subsubsection{Metacyclogenesis}

Epimastigotes were present in SMM98 on all counting days with a substantial decline from days 7 to 13 , whereas trypomastigotes appeared in early differentiation (hour zero), reduced drastically by day 4 , and began growing again up to day 13. Some epimastigotes were found at 23 days, but numbers increased sharply after the $27^{\text {th }}$ day, and decreased again between 30 and 33 days. SMM98 showed maximum growth after the $33^{\text {th }}$ day and decayed again after the $40^{\text {th }}$. Trypomastigotes showed maximum differentiation on day 20 , decreased at day 23 , then increased gradually again until day 30 . They declined again after day 37 , and then finally increased again at the $40^{\text {th }}$ day of differentiation. The highest rates of metacyclogenesis $(>70 \%)$ were observed around 20 days (Figure 1B). SMM36 differed from the previous sample because differentiation began on day 4, after which trypomastigotes appeared throughout the exponential growth phase until day 17, with a small reduction by day 20 . Epimastigotes substantially declined from days 4 to 17, growing again after day 20. Epimastigotes were present from day 23 with a significant increasing on day 40 , whereas trypomastigotes were present between days 23 and 40, but with sharp decline in the latter, resulting in a very small number of cells. The highest rates of metacyclogenesis in SMM36 (>90\%) occurred on the $17^{\text {th }}$ day (Figure 1C). SMM36 and SMM98 had the highest rates of metacyclogenesis, with about $40 \%$ after 33 and 37 days. Mean metacyclogenesis rates for both samples were lower than 30\% (Figure 1B-D). SMM1 had epimastigote forms throughout the growth curve, whereas trypomastigotes appeared only from day 7 . This sample showed maximum growth at day 10 , decreasing on the $17^{\text {th }}$ day and returning to slight growth at day 20 . The highest rates of metacyclogenesis were observed on days 10 and 13 (>20\%). SMM1 showed less differentiation than all other analyzed samples (Figure 1B).

\subsection{Classic morphometry}

The morphological aspects of epimastigote and trypomastigotes were analyzed via differences in length. For this analysis, we chose the $10^{\text {th }}$ day epimastigotes, and the $17^{\text {th }}$ and the $20^{\text {th }}$ day trypomastigotes. SMM1 parasites were shorter than in other isolates. For epimastigotes at the $10^{\text {th }}$ day (Table 1), sample SMM36 had the greatest length values $(C)$ (mean \pm Standard Deviation - S.D. $=22.9 \pm 4.1$ ), as well as the greatest flagellum length values $(F)(9.0 \pm 2.4)$. SMM1 had the greatest body width $(\mathrm{L})($ mean \pm S.D. $=2.3 \pm 0.3)$ and $\mathrm{NI}=5.4 \pm 1.7)$. For trypomastigotes in day $17, \mathrm{SMM} 36$ had the greatest length (C) (mean \pm S.D. $=20.1 \pm 3.3$, flagellum length (F) $(5.8 \pm 1.9)$ and $\mathrm{KI}=0.3 \pm 0.1$ (Table 2). SMM98 had slightly greater body width (mean \pm S.D. $=0.9 \pm 0.2$ ) compared to other samples, however the difference was not significant. SMM1 was similar to other samples in kinetoplast index value $(0.2 \pm 0.2)$. Trypomastigotes forms on day 20 significantly differed among samples for all variables tested $(\mathrm{P}<0.01)$. SMM36 had the highest values for body length (C), body width (L), flagellum (F), and nuclear index (NI). The KI, although higher in SMM1, was similar among samples (Table 2). These results indicate that the samples are morphologically heterogeneous. The Principal Components Analysis showed a significant differentiation between the SMM98 isolated and samples SMM36, and SMM1 (Figure 2A). This result was reinforced by the cluster analysis (Figure 2B).

\subsection{Ultrastructural analysis}

Forms were detected in all sections that were morphologically identical to T. cruzi, including the presence of 'rosettes' characteristics of this parasite. In ultrathin 
Table 1. Epimastigote measures $(\mu \mathrm{M})$ in Trypanosoma cruzi samples on the 10th day of the growth curve in liver infusion tryptose (LIT) medium. The data represent the mean and standard deviation; amplitude is indicated in brackets (maximum and minimum).

\begin{tabular}{cccccc}
\hline \multirow{2}{*}{ Samples } & \multicolumn{5}{c}{ Parameters measured } \\
\cline { 2 - 6 } & $\mathbf{N}$ & $\mathbf{C}$ & $\mathbf{L}$ & $\mathbf{F}$ & IN \\
\hline SMM 98 & 30 & $19.1 \pm 4.6$ & $1.6 \pm 0.3$ & $6.4 \pm 2.8$ & $0.4 \pm 0.1$ \\
& & $(12.2-29.6)$ & $(1.1-2.2)$ & $(2.2-13.9)$ & $(0.2-0.7)$ \\
SMM 36 & \multirow{2}{*}{30} & $22.9 \pm 4.1$ & $2.1 \pm 0.4$ & $9.0 \pm 2.4$ & $0.3 \pm 0.1$ \\
& & $(15.2-30.5)$ & $(1.3-2.8)$ & $(4.4-13.1)$ & $(0.2-0.7)$ \\
SMM 1 & \multirow{2}{*}{30} & $17.8 \pm 4.0$ & $2.3 \pm 0.3$ & $4.7 \pm 1.7$ & $5.4 \pm 1.7$ \\
& & $(9.6-25.2)$ & $(1.7-3.0)$ & $(2.2-9.6)$ & $(2.2-9.6)$ \\
\hline
\end{tabular}

$\mathrm{N}=$ number of specimens; $\mathrm{C}=$ body length (without a flagellum); $\mathrm{L}=$ body width (at the middle of the nucleus); $\mathrm{F}=$ free length of the flagellum; IN = nuclear index. Samples SMM98, 36 and 1: initial letters indicate Santa Maria Madalena, Rio de Janeiro state, Brazil.

Table 2. Measures of Trypanosoma cruzi trypomastigotes samples $(\mu \mathrm{M})$ on the $17^{\text {th }}$ and $20^{\text {th }}$ day of the growth curve in liver infusion tryptose (LIT) medium. The data represent the mean \pm standard deviation; amplitude is indicated in brackets (minimum and maximum).

\begin{tabular}{|c|c|c|c|c|c|c|}
\hline \multirow{2}{*}{ Samples } & \multicolumn{6}{|c|}{ Measurement parameters } \\
\hline & $\mathbf{N}$ & $\mathbf{C}$ & $\mathbf{L}$ & $\mathbf{F}$ & IN & IK \\
\hline \multirow{4}{*}{ SMM 98} & \multirow{4}{*}{20} & \multicolumn{5}{|c|}{$17^{\text {th }}$ day } \\
\hline & & $\begin{array}{c}15.9 \pm 2.6 \\
(12.2-20.9)\end{array}$ & $\begin{array}{l}0.9 \pm 0.2 \\
(0.4-1.3)\end{array}$ & $\begin{array}{l}4.6 \pm 1.9 \\
(0.9-8.7)\end{array}$ & $\begin{array}{l}1.2 \pm 0.6 \\
(0.7-2.7)\end{array}$ & $\begin{array}{l}0.2 \pm 0.1 \\
(0.1-0.4)\end{array}$ \\
\hline & & \multicolumn{5}{|c|}{$20^{\text {th }}$ day } \\
\hline & & $\begin{array}{c}16.9 \pm 2.7 \\
(13.1-22.6)\end{array}$ & $\begin{array}{l}0.8 \pm 0.2 \\
(0.4-1.3)\end{array}$ & $\begin{array}{l}4.3 \pm 2.0 \\
(0.9-7.8)\end{array}$ & $\begin{array}{l}1.0 \pm 0.4 \\
(0.5-2.0)\end{array}$ & $\begin{array}{l}0.3 \pm 0.2 \\
(0.0-1.0)\end{array}$ \\
\hline \multirow{4}{*}{ SMM36 } & \multirow{4}{*}{20} & \multicolumn{5}{|c|}{$17^{\text {th }}$ day } \\
\hline & & $\begin{array}{c}20.1 \pm 3.3 \\
(15.2-26.1)\end{array}$ & $\begin{array}{l}0.8 \pm 0.2 \\
(0.4-1.3)\end{array}$ & $\begin{array}{l}5.8 \pm 1.9 \\
(2.2-8.7)\end{array}$ & $\begin{array}{l}1.0 \pm 0.5 \\
(0.5-3.0)\end{array}$ & $\begin{array}{l}0.3 \pm 0.1 \\
(0.3-1.2)\end{array}$ \\
\hline & & \multicolumn{5}{|c|}{$20^{\text {th }}$ day } \\
\hline & & $\begin{array}{c}19.1 \pm 4.3 \\
(13.1-27.0)\end{array}$ & $\begin{array}{l}0.8 \pm 0.2 \\
(0.4-1.1)\end{array}$ & $\begin{array}{l}5.9 \pm 2.2 \\
(2.2-8.7)\end{array}$ & $\begin{array}{l}1.1 \pm 0.8 \\
(0.5-2.0)\end{array}$ & $\begin{array}{l}0.2 \pm 0.2 \\
(0.3-1.2)\end{array}$ \\
\hline \multirow{5}{*}{ SMM1 } & \multirow{5}{*}{20} & \multicolumn{5}{|c|}{$17^{\text {th }}$ day } \\
\hline & & $\begin{array}{c}9.4 \pm 6.9 \\
(0.0-18.3)\end{array}$ & $\begin{array}{l}0.8 \pm 0.6 \\
(0.0-2.1)\end{array}$ & $\begin{array}{l}3.3 \pm 2.7 \\
(0.0-7.8)\end{array}$ & $\begin{array}{l}1.0 \pm 0.3 \\
(0.6-1.7)\end{array}$ & $\begin{array}{l}0.2 \pm 0.2 \\
(0.0-0.8)\end{array}$ \\
\hline & & \multicolumn{5}{|c|}{$20^{\text {th }}$ day } \\
\hline & & $9.0 \pm 6.7$ & $0.7 \pm 0.6$ & $3.1 \pm 3.2$ & $0.9 \pm 0.4$ & $0.3 \pm 0.3$ \\
\hline & & $(0.0-16.5)$ & $(0.0-1.7)$ & $0.0-13.1$ & $(0.2-1.8)$ & $0.0-1.2$ \\
\hline
\end{tabular}

$\mathrm{N}=$ number of specimens; $\mathrm{C}=$ body length (without a flagellum); $\mathrm{L}=$ body width (at the middle of the nucleus); $\mathrm{F}=$ free length of the flagellum; IN = nuclear index; IK = kinetoplast index. Samples SMM98, 36 and 1: initial letters indicate Santa Maria Madalena, Rio de Janeiro state, Brazil.

sections, we noted the presence of a nucleus, kinetoplast, flagellum, some parasites in cell division, Golgi, cytoplasmic inclusions, and other structures typical of this flagellate (Figures 3, 4).

\section{Discussion}

Trypanosoma cruzi is a parasite with a high intraspecific variability, but despite of this, a series of characteristics was listed by Barreto and Ribeiro (1979) as being determinants for new isolates to be considered belonging to this species. This parasite grows easily in several conventional culture media, such as NNN, LIT and others at about $27^{\circ} \mathrm{C}$ and also in many types of cell culture media, with maximum growth evident between days 14 and 18 (Wynne de Martini et al., 1980). Growth curves and morphological characteristics can vary among samples. Studies on mice, indicated that the CL, FL, MR strains can show amastigote aggregates in the early stages, followed flagellated forms, while the $\mathrm{Y}$ and Berenice strains rarely give rise to amastigotes, only showing epimastigotes and rosette forms (Amaral et al., 1975). Mello et al. (1980) studying growth and differentiation in vitro in LIT of $T$. cruzi strains isolated from wild animals verified that the four strains studied presented distinct behaviors. Strains such as the CL, FL and MR show predominance of broad forms (stout), which initially present fine forms (as found in Y and Berenice strains) tend to maintain their form without 
A

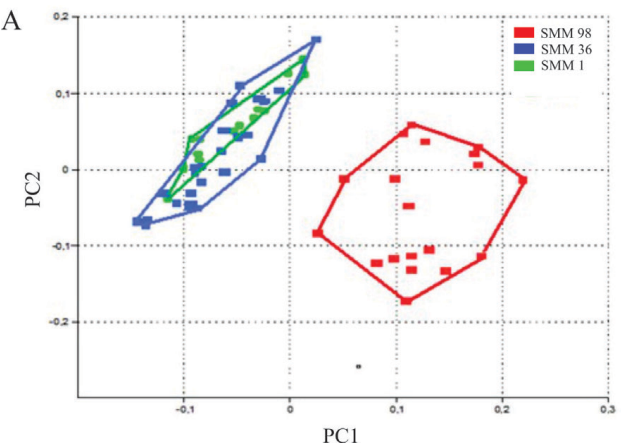

B

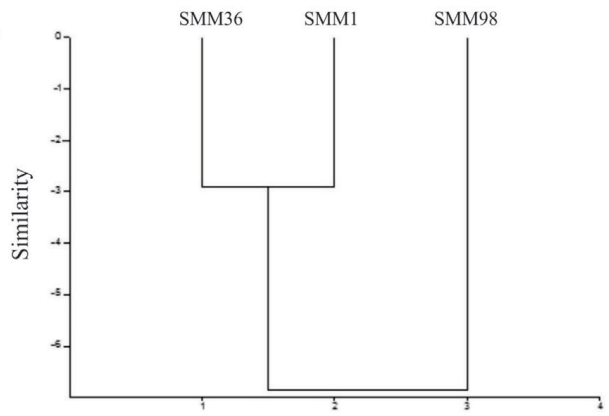

Figure 2. (A) Principal Component Analysis (PCA) show epimastigotes of Trypanosoma cruzi isolated from Triatoma vitticeps on the 10th day of the growth curve in samples SMM98, SMM36 and SMM1; (B) Dendrogram show epimastigote forms of $T$. cruzi isolated from Triatoma vitticeps on the 10th day of the growth curve. Dendogram was based on normalized mean values obtained by Principal Components Analysis. Samples SMM98, 36 and 1: initial letters indicate Santa Maria Madalena, Rio de Janeiro state, Brazil. PC1 = Principal Component 1; PC2 $=$ Principal Component 2 .
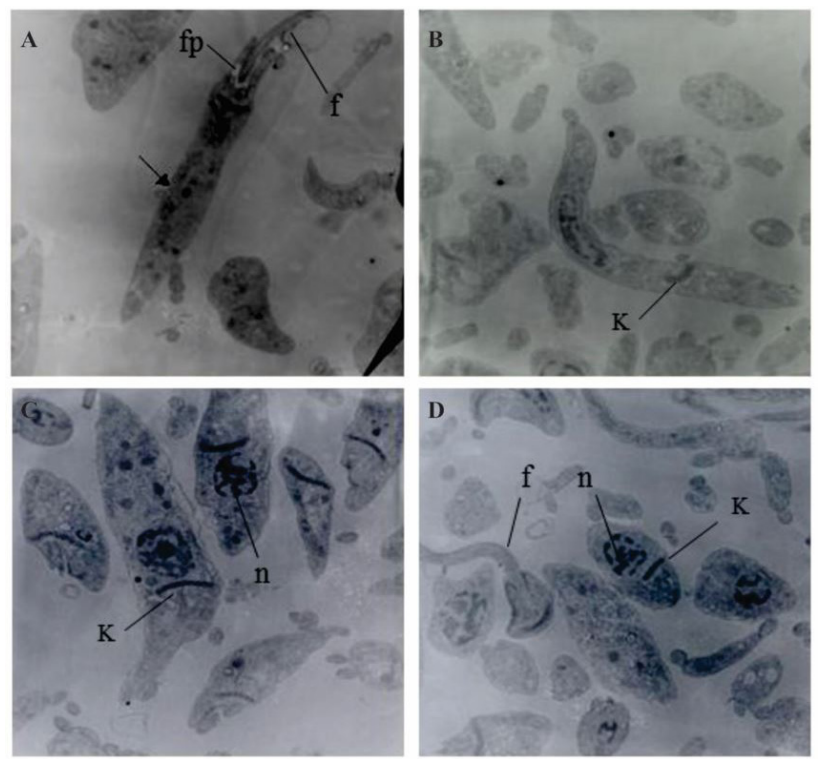

Figure 3. Transmission electron micrographs of Trypanosoma cruzi forms isolated from Triatoma vitticeps to $7.000 \mathrm{x}$. (A) and (B) sample SMM98; (C) sample SMM36; (D) sample SMM1. Lines: $\mathrm{f}=$ flagellum; $\mathrm{fp}=$ flagelar pocket; $\mathrm{n}=$ nucleus; $\mathrm{K}=$ kinetoplast; subpellicular microtubules. showing amastigotes (Schaub, 1989). However, our in vitro results indicated a strong heterogeneity between samples from the same culture medium and under the same experimental conditions.

The highest rates of differentiation were observed between the $10^{\text {th }}$ and the $20^{\text {th }}$ days for SMM1 and, SMM36 $(>90 \%)$, and on the $20^{\text {th }}$ day for SMM98 (>70\%). Cell differentiation in SMM36 and SMM98 (i.e., samples that were observed until the $40^{\text {th }}$ day) showed the highest rates of metacyclogenesis with more than $40 \%$ after days 33 and 37 , respectively. Cell differentiation of samples was due to the transformation of forms found in the culture medium. Analysis of differentiation revealed that parasite forms in different samples underwent different modifications. Considering that two of the analyzed samples came from the same location, these results demonstrate variation in behavior that is consistent with the observations proposed by Martínez-Díaz et al. (2001). Studies conducted by Ballesteros-Rodea et al. (2012), showed differences in growth curves among different sample types, a result also observed by Barr et al. (1990). The authors analyzed isolate parameters and found heterogeneity among samples isolated from dog, opossum, and armadillo. Growth curves in LIT medium from dog isolate began the exponential growth phase on day 3 , then increased markedly until day $12\left(5.0 \times 10^{7}\right.$ parasites $\left./ \mathrm{ml}\right)$, with a stationary phase of six days and subsequent gradual decline. Sylvatic samples entered in the exponential growth phase between days 6 and 9, peaking at the day 18 and rapidly declining after 21 days. The armadillo sample growth curve was slightly greater than in the dog sample, but the opossum sample had the highest at $6.0 \times 10^{7}$ parasites $/ \mathrm{ml}$. Similar results were also observed by Gomes et al. (2003), in 

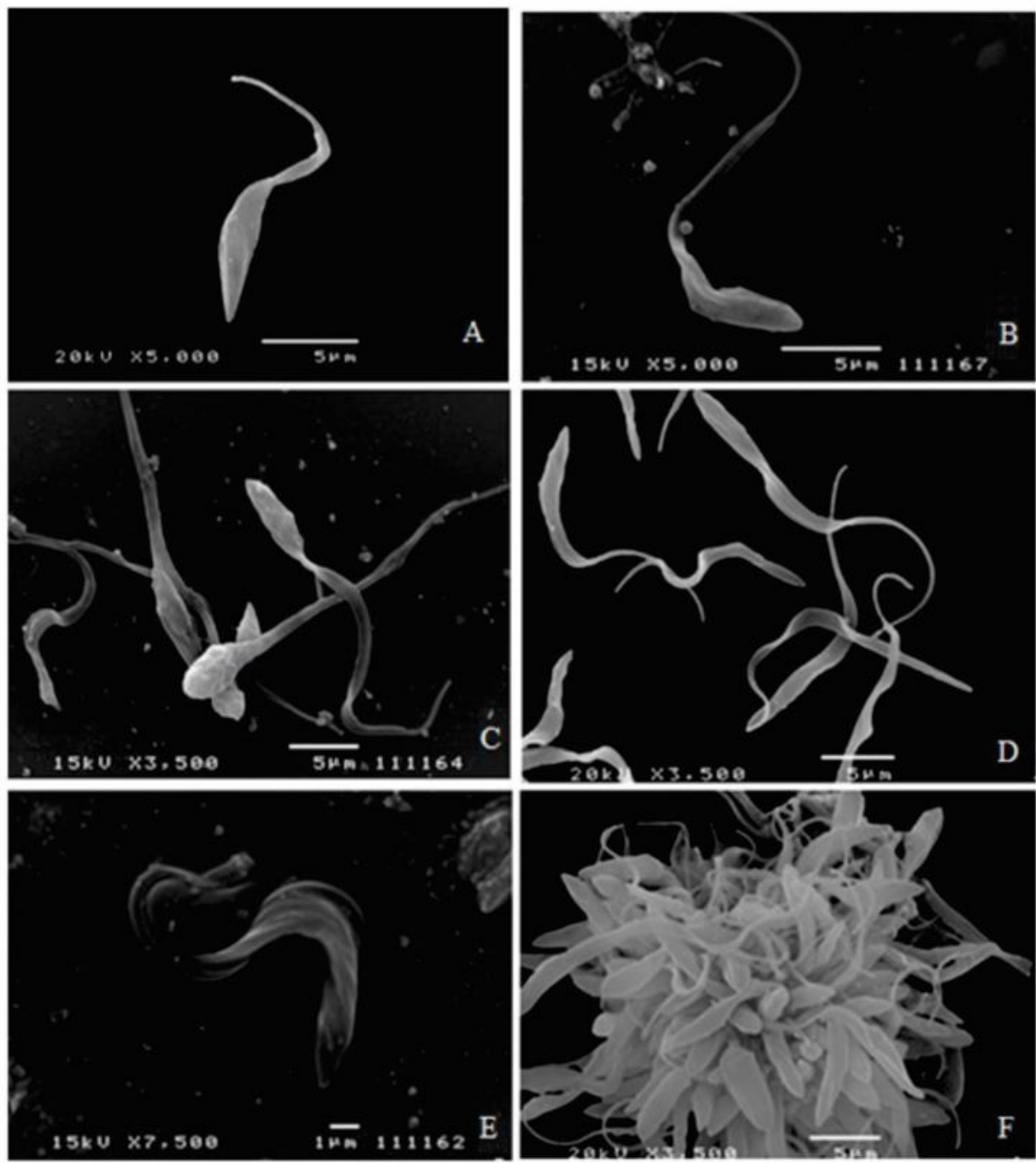

Figure 4. Scanning electron microscopy of Trypanosoma cruzi forms isolated from Triatoma vitticeps to $7.000 \mathrm{x}$. (A) and (B) SMM98; (C) and (D) SMM36; (E) and (F) SMM 1. Samples SMM98, 36 and 1: initial letters indicate Santa Maria Madalena, Rio de Janeiro state, Brazil.

which metacyclogenesis rates if used in M16 medium, whereas using the LIT medium, these rates had become much reduced by about 0.8 to $12.2 \%$. This demonstrates specific characteristics in biological samples from $T$. cruzi, from chronic Chagas patients from the State of Paraná, Brazil when cultured in M16.

Castellani et al. (1967) indicated that the final differentiation of epimastigotes and metacyclic trypomastigotes, as well as forming of rosettes during development, are the result of metacyclogenesis. The Y strain develops an intense metacyclogenesis process after 48 hours of culture in LIT - HIL medium, replacing liver infusion by canine heart infusion and tryptose by hydrolyze albumin. Bonaldo et al. (1988) showed that T. cruzi epimastigotes adhere to culture flasks prior to metacyclic differentiation, suggesting that adhesion to the substrate is an important stimulus for the cellular differentiation process. The importance of adhering for multiplication and differentiation of epimastigotes of T. cruzi and other trypanosomatids has been extensively studied over the years, and many theories were formulated in order to establish the factors that regulate this phenomenon. These results are in agreement with the observations proposed by Edelman (1985) in that the morphogenic process of different higher eukaryotic cells is preceded by cell-to-cell adhesion.

This study also demonstrates the importance of the morphometric analysis as taxonomic tool for identification of T. cruzi, taking into account the gap for this type of study. This parasite has been described as a monotypic species, and studies of populations from different origins have demonstrated heterogeneity in relation to the morphology of blood forms, virulence, pathogenicity, and susceptibility to vertebrate host cells (Brener, 1969).

Morphological analysis via SEM in pre-established culture showed significant morphological differences among parasites throughout the time period examined. 
The current study suggests that two isolates we analyzed belong to closely related groups, with the exception of sample SMM1. Univariate and multivariate analyses showed that epimastigote forms were found on the $10^{\text {th }}$ day for sample SMM98, and that is was the only one with significant morphological differences. Other studies also demonstrated inter-sample heterogeneity with respect to epimastigote length and kinetoplast content (Gonçalves, 2000; Santos-Mallet et al., 2008; Silva et al., 2008). Heterogeneity in T. cruzi populations regarding infectivity, virulence, morphology, and pathogenicity has been demonstrated in several studies. Moreover, intraspecific variability of $T$. cruzi at the genetic level has also been broadly confirmed (Andrade, 1985; Tibayrenc and Ayala, 1988; Tibayrenc et al., 1986).

Some evidence has suggested that the existence of distinct populations of $T$. cruzi could be related to distinct clinical manifestations of Chagas disease, which is a matter of great epidemiological importance (Luquetti et al., 1986; Tibayrenc and Ayala, 1988; Macedo and Pena, 1998). In this way, a "strain" can be differentiated from others not only genetically, but also by one or more epidemiologically important features. Parasites strains should then be described through a combination of genetic and biological characteristics. The heterogeneity between T. cruzi samples may be the result of an eclectic food on a myriad of reservoirs, as well as a reflection of human action, which could change the pattern of triatomine and/or reservoir dispersion, thereby driving parasite differentiation (Gonçalves, 2000).

Trypanosoma cruzi adaptation to various hosts in different environments leads to complex regulation of gene expression, possibly resulting in morphological changes that are observable during parasite transformation. Several studies of factors related to the physiological stress of parasites have demonstrated that temperature, nutritional status, and $\mathrm{pH}$ can stimulate morphological differentiation during amastigogeneses (Tomlinson et al., 1995; Macedo and Pena, 1998; Navarro et al., 2003; Hernandez-Osorio et al., 2010).

\section{Conclusions}

The morphological features observed in the growth curves of our isolates showed pronounced inter and intra populational variability. Samples heterogeneity of the samples is also confirmed by the fact that our isolates differed from standard strains in both growth curve and morphology. By monitoring cell differentiation and assessing metacyclogenesis rates, we found that all the analyzed samples exhibit different morphobiological behaviors, either among them or in relation to previously studied and standard strains. SMM 98 had a distinctly different size than the other groups studied, however with the same characteristics described for standard strains of T. cruzi. As previous studies have demonstrated distinct profiles in mouse infection, further studies shall be conducted to test the infectivity pattern of each of these isolates.
Ultrastructural analysis of isolates by scanning electron microscopy (SEM) indicated morphological patterns of epimastigotes and trypomastigote indistinguishable from standard T. cruzi strains. Similarly, transmission electron microscopy (TEM) revealed morphological similarities in the kinetoplast, flagellar pocket, subpellicular microtubules, and core scourge among others. All these features are compatible with structures found in standard T. cruzi strains. Sample heterogeneity, as revealed through microbiological studies may contribute to studies of different clinical manifestations of Chagas disease.

\section{Acknowledgements}

The authors thank "Fundação Carlos Chagas Filho de Amparo à Pesquisa do Estado do Rio de Janeiro (FAPERJ); Coordenação de Aperfeiçoamento de Pessoal de Nível Superior (CAPES); Instituto Oswaldo Cruz, Fundação Oswaldo Cruz (IOC-FIOCRUZ), Brasil”.

\section{References}

AMARAL, C.F.S., TAFURI, W.L. and BRENER, Z., 1975. Frequência do parasitismo encefálico em camundongos experimentalmente inoculados com diferentes cepas de Trypanosoma cruzi. Revista da Sociedade Brasileira de Medicina Tropical, vol. 9, no. 5, pp. 243-246. http://dx.doi.org/10.1590/S0037-86821975000500004.

ANDRADE, S.G.G., 1985. Morphological and behavioral characterization of Trypanosoma cruzi strains. Revista da Sociedade Brasileira de Medicina Tropical, vol. 18, no. 1, pp. 39-46. http:// dx.doi.org/10.1590/S0037-86821982000100004.

BALLESTEROS-RODEA, G., SANTILLÁN, M., MARTÍNEZCALVILLO, S. and MANNING-CELA, R., 2012. Flagellar motility of Trypanosoma cruzi epimastigotes. Journal of Biomedicine \& Biotechnology, vol. 2012, pp. 520380. http:// dx.doi.org/10.1155/2012/520380. PMid:22287834.

BARR, S.C., DENNIS, V.A. and KLEI, T.R., 1990. Growth characteristic in axenic and cell cultures, proteins profiles, and zymodeme typing of three Trypanosoma cruzi isolates from Louisiana mammals. The Journal of Parasitology, vol. 76, no. 5, pp. 631-638. http://dx.doi.org/10.2307/3282972. PMid:2213406.

BARRETO, M.P., 1965. Trypanosomos semelhantes ao Trypanosoma cruzi em animais silvestres e sua identificação como o agente etiológico da doença de Chagas. Revista da Sociedade Brasileira de Medicina Tropical, vol. 7, pp. 305-315.

BARRETO, M.P. and RIBEIRO, R.D., 1979. Reservatórios silvestres do Trypanosoma (Schizotrypanum) cruzi Chagas 1909. Revista do Instituto Adolfo Lutz, vol. 39, pp. 25-36.

BONALDO, M.C., SOUTO-PADRON, T., DE-SOUZA, W. and GOLDENBERG, S., 1988. Cell-substrate adhesion during Trypanosoma cruzi differentiation. The Journal of Cell Biology, vol. 106, no. 4, pp. 1349-1358. http://dx.doi.org/10.1083/ jcb.106.4.1349. PMid:3283152.

BRENER, Z., 1969. The behavior of slender and forms of Trypanosoma cruzi in the blood-stream of normal and immune mice. Annals of Tropical Medicine and Parasitology, vol. 63, no. 2, pp. 215-220. http://dx.doi.org/10.1080/00034983.1969.1 1686622. PMid:4984495. 
CAMARGO, E.P., 1964. Growth and differentiation in Trypanosoma cruzi. I. Origin of metacyclic trypanosomes in liquid media. Revista do Instituto de Medicina Tropical de São Paulo, vol. 6, pp. 93-100. PMid:14177814.

CASTELLANI, O., RIBEIRO, L.V. and FERNANDES, J.F., 1967. Differentiation of Trypanosoma cruzi in culture. The Journal of Protozoology, vol. 14, no. 3, pp. 447-451. http:// dx.doi.org/10.1111/j.1550-7408.1967.tb02024.x. PMid:6050651.

COURA, J.R., 2013. Chagas disease: control, elimination and eradication. Is it possible? Memórias do Instituto Oswaldo Cruz, vol. 108, no. 8, pp. 962-967. http://dx.doi.org/10.1590/00740276130565. PMid:24402148.

DEVERA, R., FERNANDES, O. and COURA, J.R., 2003. Should Trypanosoma cruzi be called "cruzi" complex? A review of the parasite diversity and the potential of selecting population after in Vitro culturing and mice infection. Memórias do Instituto Oswaldo Cruz, vol. 98, no. 1, pp. 1-12. http://dx.doi.org/10.1590/ S0074-02762003000100001. PMid:12700855.

DIAS, J.C.P., 1940. Sobre um Schizotrypanum dos morcegos Lonchoglossa ecaudata e Carollia perspicillata do Brasil. Memórias do Instituto Oswaldo Cruz, vol. 35, no. 2, pp. 399-411. http:// dx.doi.org/10.1590/S0074-02761940000200012.

EDELMAN, G.M., 1985. Molecular determinants of animal form. Journal of Cellular Biochemistry, vol. 29, no. 3, pp. 253263. http://dx.doi.org/10.1002/jcb.240290606. PMid:3001111.

FORATTINI, O.P., 1980. Biogeografia, origem e distribuição da domicialização de triatomíneos no Brasil. Revista de Saúde Publica, vol. 14, no. 3, pp. 265-299. http://dx.doi.org/10.1590/ S0034-89101980000300002. PMid:7015472.

GARCIA, S.L., RODRIGUES, V.L.C.C., GARCIA, N.L. and MELLO, M.L.S., 2011. Prevalence and intensity of infection, metacyclogenesis and nuclear phenotypes in Panstrongylus megistus (Burmeister, 1835) after ingestion of Trypanosoma cruzi (Chagas, 1909) II and sunjection to heat shock. Brazilian Journal of Biology $=$ Revista Brasileira de Biologia, vol. 71, no. 2, pp. 491-500. http://dx.doi.org/10.1590/S1519-69842011000300020. PMid:21755168.

GOMES, M.L., TOLEDO, M.J.O., NAKAMURA, C.V., BITTENCOURT, N.L.R., CHIARI, E. and ARAÚJO, S.M., 2003. Trypanosoma cruzi: genetic group with peculiar and biochemical behavior. Memórias do Instituto Oswaldo Cruz, vol. 98, no. 5, pp. 649-654. http://dx.doi.org/10.1590/S0074-02762003000500011. PMid:12973532.

GONÇALVES, T.C.M., 2000. Aspectos ecológicos de Triatoma vitticeps (Stål, 1859) (Hemiptera, Reduviidae), com caracterização das amostras de Trypanosoma cruzi Chagas, 1909 (Kinetoplastida, Trypanosomatidae) isoladas desse triatomíneo, no município de Santa Maria Madalena, Estado do Rio de Janeiro. Rio de Janeiro: Fundação Oswaldo Cruz, 125 p. Tese de Doutorado em Biologia Parasitária.

GONÇALVES, T.C.M., OLIVEIRA, E., DIAS, L.S., ALMEIDA, M.D., NOGUEIRA, W.O. and ÁVILA-PIRES, F.D., 1998. An investigation on the ecology of Triatoma vitticeps (Stål, 1859) and its possible role in the transmission of Trypanosoma cruzi, in the locality of Triunfo, Santa Maria Madalena municipal district, state of Rio de Janeiro, Brazil. Memórias do Instituto Oswaldo Cruz, vol. 93, no. 6, pp. 711-717. http://dx.doi.org/10.1590/ S0074-02761998000600002. PMid:9921289.

HERNÁNDEZ-OSORIO, L.A., MÁRQUEZ-DUEÑAS, C., FLORENCIO-MARTÍNEZ, L.E., BALLESTEROS-
RODEA, G., MARTÍNEZ-CALVILLO, S. and MANNINGCELA, R.G., 2010. Improved method for in vitro secondary amastigogenesis of Trypanosoma cruzi: morphometrical and molecular analysis of intermediate developmental forms. Journal of Biomedicine \& Biotechnology, vol. 2010, pp. 1-10. http://dx.doi. org/10.1155/2010/283842. PMid:20037731.

HOARE, C.A., 1972. The Trypanosomes of mammals: a zoological monograph. Oxford: Blackwell Scientific Publications, 749 p.

LENT, H., 1942. Transmissores da moléstia de Chagas no estado do Rio de Janeiro. Revista Fluminense de Medicina, vol. 6, pp. 1-13.

LUQUETTI, A.O., MILES, M.A., RASSI, A., REZENDE, J.M., SOUZA, A.A., PÓVOA, M.M. and RODRIGUES, I., 1986. Trypanosoma cruzi: zymodeme associated with acute and chronic Chagas disease in Central Brazil. Transactions of the Royal Society of Tropical Medicine and Hygiene, vol. 80, no. 3, pp. 462-470. http://dx.doi.org/10.1016/0035-9203(86)90347-0. PMid:3099437.

MACEDO, A.M. and PENA, S.D.J., 1998. Genetic variability of Trypanosoma cruzi implications for the pathogenesis of Chagas disease. Parasitology Today, vol. 14, no. 3, pp. 119-124. http:// dx.doi.org/10.1016/S0169-4758(97)01179-4. PMid:17040719.

MARTÍNEZ-DÍAZ, R.A., ESCARIO, J.A., NOGAL-RUIZ, J.J. and GÓMEZ-BARRIO, A., 2001. Biological characterization of Trypanosoma cruzi strains. Memórias do Instituto Oswaldo Cruz, vol. 96, no. 1, pp. 53-59. http://dx.doi.org/10.1590/S007402762001000100006 . PMid:11285475.

MELLO, D.A., BORGES, M.M. and CHIARINI, L.H., 1980. Crescimento e diferenciação celular "in vitro" de cepas de Trypanosoma cruzi, isolada de animais silvestres. Revista de Saúde Pública de São Paulo, vol. 14, no. 4, pp. 569-581. http:// dx.doi.org/10.1590/S0034-89101980000400012.

MOSER, D.R., KIRCHHOFF, L.V. and DONELSON, J.E., 1989. Detection of Trypanosoma cruzi by DNA amplification using the polymerase chain reaction. Journal of Clinical Microbiology, vol. 27, no. 7, pp. 1477-1482. PMid:2504769.

NAVARRO, M.C., LIMA, A.R., ASKUE, J. and CONTRERAS, V.T., 2003. Morphological comparation of axenic amastigogenesis of trypomastigotes and metaciclogenesis forms of Trypanosoma cruzi. Memórias do Instituto Oswaldo Cruz, vol. 98, no. 1, pp. 83-91. http://dx.doi.org/10.1590/S0074-02762003000100012. PMid: 12700866

NICOLLE, G.L., 1908. Culture du parasite du Boutond' Orient. Compte Rendu Hebdomadaire des Sciences de l'Academie des Sciences, vol. 146, pp. 842-843.

NOVY, F.G. and MCNEAL, W.J., 1904. On the cultivation of Trypanosoma brucei. The Journal of Infectious Diseases, vol. 1, no. 1, pp. 1-30. http://dx.doi.org/10.1093/infdis/1.1.1.

RIBEIRO, C.A.O., REIS FILHO, H.S. and GROTZNER, S.R., 2012. Técnicas e métodos para utilização pratica em microscopia. 1. ed. São Paulo: Santos Grupo Gen, 440 p.

SANGENIS, L.H., SARAIVA, R.M., GEORG, I., CASTRO, L., SANTOS LIMA, V., ROQUE, A.L., XAVIER, S.C., SANTOS, L.C., FERNANDES, F.A., SARQUIS, O., LIMA, M.M., CARVALHO-COSTA, F.A. and BÓIA, M.N., 2015. Autochthonous transmission of Chagas disease in Rio de Janeiro States, Brazil: a clinical and eco-epidemiological study. BMC Infectious Diseases, vol. 15, no. 4, pp. 1-12. PMid:25566786.

SANTOS, C.B., LEITE, G.R., SESSA, P.A. and FALQUETO, A., 2006. Dynamics of feeding and defecation in Triatoma 
vitticeps (Stål, 1859) (Hemiptera, Reduviidae, Triatominae) and its potential in the transmission of Trypanosoma cruzi. Memórias do Instituto Oswaldo Cruz, vol. 101, no. 5, pp. 543-546. http:// dx.doi.org/10.1590/S0074-02762006000500010. PMid:17072459.

SANTOS-MALLET, J.R., SILVA, C.S., GOMES, S.A.O., OLIVEIRA, D.L., SANTOS, C.L., SOUSA, D.M., PINHEIRO, N.L., JUNQUEIRA, A.C.V. and GONÇALVES, T.C.M., 2008. Molecular characterization of Trypanosoma cruzi sylvatic isolates from Rio de Janeiro, Brazil. Parasitology Research, vol. 103, no. 5, pp. 1041-1045. http://dx.doi.org/10.1007/s00436-008-1089-y. PMid:18622628.

SCHAUB, G., 1989. Trypanosoma cruzi: Quantitative studies of development of two strains in small intestine and rectum of the vector Triatoma infestans. Experimental Parasitology, vol. 68, no. 3, pp. 260-273. http://dx.doi.org/10.1016/0014-4894(89)90108-2. PMid:2649388.

SILVA, C.S., 2006. Estudo morfobiológico e histopatológico de amostras silvestres de Trypanosoma cruzi isoladas de Triatoma vitticeps (Stål, 1959) no Estado do Rio de Janeiro. Rio de Janeiro: Universidade Federal Rural do Rio de Janeiro, 85 p. Dissertação de Mestrado em Biologia Animal.

SILVA, C.S., SANTOS-MALLET, J.R., LOPES, C.M. and GOMES, S.A.O., 2008. Infecção experimental em camundongos infectados por Trypanosoma cruzi isolados de Triatoma vitticeps no município de Santa Maria Madalena, Rio de Janeiro. In: Anais da XXIV Reunião de Pesquisa em Doença de Chagas e Leishmanioses, 23-25 Outubro 2008, Uberaba. Uberaba: Sociedade Brasileira de Medicina Tropical, pp. 47.

SILVA-JUNIOR, R. and PAIVA, T.S., 2017. Evaluating the role of morphological characters in the phylogeny of some trypanosomatid genera (Excavata, Kinetoplastea, Trypanosomatida). Cladistics. http://dx.doi.org/10.1111/cla.12199.

SOUSA, M.A., CAMARGO, A.C. and COSTA, K.C.F., 1994. Differentiation to opisthomastigote in trypanosomatids allocated in the genus Crithidia. Memórias do Instituto Oswaldo Cruz, vol. 89, no. 1, pp. 224. PMid:7823806.

SOUZA, R.C.M., SOARES, A.C., ALVES, C.L., LOROSA, E.S., PEREIRA, M.H. and DIOTAIUTI, L., 2011. Feeding behavior of Triatoma vitticeps (Reduviidae: Triatominae) in the state of Minas Gerais, Brazil. Memórias do Instituto Oswaldo
Cruz, vol. 106, no. 1, pp. 16-22. http://dx.doi.org/10.1590/S007402762011000100003 . PMid:21340350.

TIBAYRENC, M. and AYALA, F.J., 1988. Isozyme variability the agent of Chagas'disease: genetical, taxonomical, and epidemiological significance. Evolution; International Journal of Organic Evolution, vol. 42, pp. 277-292. PMid:28567853.

TIBAYRENC, M., HOFFMANN, A., POCH, O., ECHALAR, L., LE PONT, F., LEMESRE, J.L., DESJEUX, P. and AYALA, F.J., 1986. Additional data on Trypanosoma cruzi isozymic strains encountered in bolivian domestic transmission cycles. Transactions of the Royal Society of Tropical Medicine and Hygiene, vol. 80, no. 3, pp. 442-447. http://dx.doi.org/10.1016/0035-9203(86)90338-X. PMid:3541308.

TOMLINSON, S., VANDEKERCKHOVE, F., FREVERT, U. and NUSSENZWEIG, V., 1995. The induction of Trypanosoma cruzi trypomastigote to amastigote transformation by low $\mathrm{pH}$. Parasitology, vol. 110, no. 5, pp. 547-554. http://dx.doi.org/10.1017/ S0031182000065264. PMid:7541124.

VALLEJO, G.A., MARINKELLE, C.J., GUHL, F. and DE SANCHEZ, N., 1988. Behavior of the infection and morphologic differentiation of Trypanosoma cruzi and T. rangeli in the intestine of the vector Rhodnius prolixus. Brazilian Journal of Biology = Revista Brasileira de Biologia, vol. 48, no. 3, pp. 577-587. PMid:3070649.

VILLA, L.M., GUHL, F., ZABALA, D., RAMÍREZ, J.D., URREA, D.A., HERNÁNDEZ, D.C., CUCUNUBÁ, Z., MONTILLA, M., CARRANZA, J.C., RUEDA, K., TRUJILLO, J.E. and VALLEJO, G.A., 2013. The identification of two Trypanosoma cruzi I genotypes from domestic and sylvatic transmission cycles in Colombia based on a single polymerase chain reaction amplification of the spliced-leader intergenic region. Memórias do Instituto Oswaldo Cruz, vol. 108, no. 7, pp. 932-935. http:// dx.doi.org/10.1590/0074-0276130201. PMid:24037107.

WORLD HEALTH ORGANIZATION - WHO, 2015 [viewed 17 October 2017]. Chagas disease in Latin America: an epidemiological update based on 2010 estimates [online]. Available from: http:// www.who.int/wer/en/

WYNNE DE MARTINI, G.J., ABRAMO ORREGO, L., RISSIO, A.M., ALVAREZ, M. and MUJICA, L.P., 1980. Cultivo de Trypanosoma cruzi em um médio monofásico. Medicina, vol. 40, suppl. 1, pp. 109-114. PMid:7005593. 